\title{
INFLUENCE OF THE REPLANTING AGE ON YIELD AND GROWTH OF EUCALYPT CLONAL STANDS
}

Geraldo Magela Pereira Filho $2^{*} \odot$, Laércio Antônio Gonçalves Jacovine ${ }^{3}$, , Bruno Leão Said Schettini $^{4}$, Haroldo Nogueira de Paiva ${ }^{3}$, , Paulo Henrique Villanova ${ }^{\circledR}$, Samuel José Silva Soares da Rocha ${ }^{\circ}$ and Hélio Garcia Leite ${ }^{3}(0)$

\footnotetext{
${ }^{1}$ Received on 26.02.2019 accepted for publication on 26.06.2019.

${ }^{2}$ Celulose Nipo Brasileira S.A, Belo Oriente, MG - Brasil. E-mail: <geraldofilho.ufla@gmail.com>.

${ }^{3}$ Universidade Federal de Viçosa, Departamento de Engenharia Florestal, Viçosa , MG - Brasil. E-mail: <jacovine@ufv.br>, <hnpaiva@ufv.br> and<hgleite@ufv.br>.

${ }^{4}$ Universidade Federal de Viçosa, Mestrado em Ciência Florestal, Viçosa, MG - Brasil. E-mail: <bruno.schettini@ufv.br>,<paulo.villanova@ufv. br> and <samuel.rocha@ufv.br>.

*Corresponding author.
}

\begin{abstract}
The growth of an eucalypt plantation should be monitored to identify factors that influence its development, helping in the decision-making process, aiming to reduce productivity losses. Thus, the objective of the present study was to evaluate the influence of the age of replanting on the yield and growth of eucalypt stands. The experiment was conducted in an area of CENIBRA S.A. Company, and established in a commercial plantation in August 2011. The application of herbicide and the ant control were performed in total area before planting. Seedlings of Eucalyptus urophylla $\times$ Eucalyptus grandis clones in $3.0 \times 2.5 \mathrm{~m}$ spacing were used. Limestone $\left(1,500 \mathrm{~kg} \mathrm{ha}^{-1}\right)$ was applied in total area before planting and $100 \mathrm{~g}$ plant-1 of NPK fertilizer (06-3006) was applied immediately after planting. Four months after the installation of the experiment, $300 \mathrm{~kg} \mathrm{ha}^{-1}$ of NPK (06-10-29) was applied. Treatments consisted of four dates of seedling replanting $(0,20,40$ and 80 days after planting) without complementary fertilization, and two treatments (replanting 40 and 80 days after planting) with supplementary fertilization (100g plant ${ }^{-1}$ NPK 06-30-06). The individual volume of replanting trees was $46.6 \%$ lower than of non-replanted ones. Treatments with complementary planting fertilization did not differ $(\mathrm{p}>0.05)$ by the T-test. It is concluded that the longer the time between planting and replanting, the smaller the individual volume of the replanting trees and that the complementary fertilization in seedlings replanted does not favor their growth.
\end{abstract}

Keywords: Forest management; Clonal forestry; Planting uniformity.

\section{INFLUÊNCIA DA ÉPOCA DO REPLANTIO NA PRODUTIVIDADE E CRESCIMENTO DE PLANTIOS CLONAIS DE EUCALIPTO}

RESUMO - O crescimento de um plantio de eucalipto deve ser monitorado, para identificar fatores que influenciam o seu desenvolvimento, auxiliando na tomada de decisões para reduzir perdas de produtividade. Assim, o objetivo do presente estudo é avaliar a influência da época de realização de replantios sobre a produtividade e o crescimento de povoamentos de eucalipto. O experimento foi conduzido em uma área da CENIBRA S.A. e implantado em um plantio comercial em agosto de 2011. A aplicação de herbicida e o controle de formigas, em área total, foram realizados antes do plantio, com mudas clonais de Eucalyptus urophylla $\times$ Eucalyptus grandis no espaçamento $3,0 \times 2,5 \mathrm{~m}$. A calagem $\left(1.500 \mathrm{~kg} \mathrm{ha}^{-1}\right)$ foi realizada em área total antes do plantio e $100 \mathrm{~g} \mathrm{planta}^{-1}$ de fertilizante NPK (06-30-06), aplicado imediatamente após o plantio. Quatro meses após a instalação do experimento, $300 \mathrm{~kg} \mathrm{ha}^{-1}$ de NPK (06-10-29) foi aplicado. Os tratamentos consistiram de quatro datas de replantio de mudas (0, 20, 40 e 80 dias após plantio) sem adubação complementar, e dois tratamentos (replantio com 40 e 80 dias do plantio) com adubação complementar de plantio (100 $\mathrm{g}_{\text {planta }}{ }^{-1}$ de NPK 06-30-06) $O$ volume individual das árvores replantadas foi 46,6\% inferior ao das não replantadas. Os tratamentos com adubação complementar de plantio não diferiram $(p>0,05)$ pelo teste t. Conclui-se que quanto maior o intervalo de tempo entre o plantio e o replantio, menor é o volume individual da árvore replantada e que a realização de adubação complementar em mudas de replantio não favorece o crescimento dessas.

Palavras-Chave: Manejo florestal; Silvicultura clonal; Uniformidade de plantio.

Silf (cx) EY

Revista Árvore 2020;44:e4402

http://dx.doi.org/10.1590/1806-908820200000002 


\section{INTRODUCTION}

Brazilian eucalyptus stands are among the most productive in the world (Soares et al., 2016; Binkley et al., 2017). The average productivity at seven years old, in the 1970 s was close to $15 \mathrm{~m}^{3}$.ha ${ }^{-1}$. year-1 (Queiroz and Barrichelo, 2007), and close to $35.7 \mathrm{~m}^{3} \mathrm{ha}^{-1} \mathrm{year}^{-1}$ in 2016 (IBÁ, 2017). To this end, it was necessary to ensure the adequacy of the technical recommendations and quality of forestry operations (Trinidad et al., 2017), which bring improvements in the distribution of inputs and ensures the development of a more uniform and productive forest. There is a positive relationship between uniformity and productivity of eucalyptus stands (Stape et al., 2010; Luu et al., 2013; Soares et al., 2016), which are affected by the quality of silvicultural operations (Radtke et al., 2003).

The presence of individuals of different ages in the stand also affects the quality of the forest and occurs due to the replanting (Correia et al., 2011). Replanting is a costly activity, and it is related to the poor quality of forest deployment activities (Chichorro et al., 2017) and when performed out of time, can lose its initial goal of ensuring the highest productivity of the stand. Late replanting causes greater competition for resources between plants, as older trees grow faster than younger trees because they use resources more efficiently (Binkley, 2004).

Dominated trees are undesirable in planted forests due to its undergrowth, susceptibility to pests and diseases (Alfenas et al., 2004) and increased vulnerability to environmental stress conditions. The increase in dominated plants within the stand causes a loss in production potential (Schneider et al., 2015). In this sense, the uniformity of a stand will only be considered critical once the heterogeneous growth of the trees generates loss of forest productivity and, consequently, economic damage.

The growth of a eucalyptus plantation should be monitored to identify factors that influence its development, helping to make decisions to correct or prevent possible productivity losses. The objective of this study was to evaluate the influence of the replanting season on the yield and growth of eucalyptus stands.

\section{MATERIAL AND METHODS}

The experiment was conducted in an area belonging to the company Celulose Nipo-Brasileira
S.A. (CENIBRA S.A.), located in the municipality of Belo Oriente, Minas Gerais, that has a Latosolic Cambisol (CXbd5). The climate is characterized as Aw (Köppen), mesothermal, tropical rainy, with annual average precipitation of $1,208 \mathrm{~mm}$, annual average temperature of $25,2^{\circ} \mathrm{C}$ and average relative humidity of $65,2 \%$. The region is located at $19^{\circ} 10^{\prime} \mathrm{S}$, $42^{\circ} 20^{\prime} \mathrm{W}$, with altitude ranging from 220 to $425 \mathrm{~m}$.

The planting of the experiment was carried out in a commercial plot deployed in August 2011, following the technical recommendations and operations of the company. Herbicide application and ant control were performed in total area before planting. Clonal seedlings of Eucalyptus urophylla trees S.T. Blake x Eucalyptus grandis Hill ex Maiden (Myrtaceae) were planted at $3.0 \times 2.5 \mathrm{~m}$ spacing. Fertilization was carried out with $1,500 \mathrm{~kg} \cdot \mathrm{ha}^{-1}$ of limestone applied in total area before planting and 100 g.plant $^{-1}$ of NPK fertilizer (06-30-06), applied immediately after planting, in two lateral holes. Four months after the installation of the experiment a cover fertilization with $300 \mathrm{~kg} \cdot \mathrm{ha}^{-1}$ NPK (06-10-29) was made.

Treatments consisted in four dates of seedling replanting $(0,20,40$ and 80 days after planting) without complementary fertilization in the planting, plus two treatments (replanting 40 and 80 days after planting) with supplementary fertilization in the planting (+ $100 \mathrm{~g} /$ plant $^{-1}$ NPK 06-30-06) (Table 1). The experiment was made in a randomized block design with four replications.

The experimental plot had nine rows with nine plants. The replanting of the nine seedlings, in which the treatments were applied, was done so that each replanted seedling had a double border of nonreplanted seedlings. The entire plot was planted, and after 12 days the seedlings of the hole to be replanted were plucked and the replanting was made according to the treatments.

The diameter at $1.3 \mathrm{~m}$ height $(D B H$, in $\mathrm{cm})$ and the height $(H$, in $\mathrm{m})$ of all plants in the plot were measured at 32 and 43 months of age. The individual volume of each tree was determined based on the adjusted equation (Equation 1), developed from CENIBRA SA inventory data.

$$
\mathrm{V}=0.014562+0.0000323 \times \mathrm{DBH}^{2} \times \mathrm{H} \quad(\text { Eq. } 1)
$$

Where:

Revista Árvore 2020;44:e4402 
$\mathrm{V}=$ Individual volume of trees, in $\mathrm{m}^{3}$;

$\mathrm{DBH}=$ Diameter at 1.30 meters high in $\mathrm{cm}$;

$\mathrm{H}=$ Tree height, in $\mathrm{m}$.

The effect of the season of replanting in the volume of individual trees and average volume increase (AMI) in the volume of replanted trees, at 43 months, was evaluated by regression with $5 \%$ of significance level in the F-test. The effect of supplementary fertilization in the planting was evaluated from the individual volume between treatment with and without supplementary fertilization in the last year of measurement, by T-test with $5 \%$ of significance. For processing the data it was used the statistical software Statistica version 12 (STATSOFT, INC., 2014).

The diametric distribution of the trees in the stand was based on the grouping of the trees in the plots in class centers with amplitude of $3.0 \mathrm{~cm}$ (class center of $1.5 \mathrm{~cm})$.

\section{RESULTS}

The individual volume of replanted trees was $46.6 \%$ lower than non-replanted trees and their lowest value $\left(\hat{y}=0.0635 \mathrm{~m}^{3}\right)$ was observed when replanting was performed 80 days after replanting. The treatments with complementary planting fertilization, performed at 40 and 80 days of replanting, did not differ $(p>0.05)$ by the T-test (Figure 1).

By the F-test, the AMI was not significantly affected, considering the trees in these plots, the different treatments, despite the reduction in volume of individual trees according to the replanting season (Table 1 and Figure 2).

The trees with larger DBH measured after 32 months were those with the largest increase in $\mathrm{DBH}$ at 43 months of age. The largest increase in DBH was observed in the individuals that the replanting was performed 20 days after planting, while the lowest value was in replanting that occurred 40 days after planting (Figure 3).

The diametric classes of lower value showed the smallest migration of trees to the class above. The 15.5 cm class center had an increased percentage from 9.10 to $31.00 \%$, and after 43 months, $18.5 \%$ individuals entered the class center (Table 2).

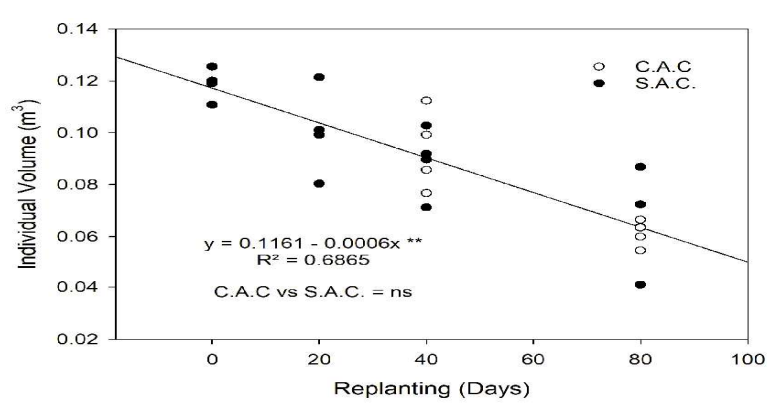

Figure 1 - Individual volume of Eucalyptus urophylla $\times$ Eucalyptus grandis trees at 43 months of age, influenced by the replanting season without complementary planting fertilizer (S.A.C.) and with complementary planting fertilizer (C.A.C.), at 40 and 80 days of replanting. $* *=$ significant, at $5 \%$ probability; and ns $=$ not significant.

Figura 1 - Volume individual das árvores de Eucalyptus urophylla $\times$ Eucalyptus grandis aos 43 meses de idade, influenciadas pela época de replantio sem adubação complementar (S.A.C.) e com adubação complementar (C.A.C.), aos 40 e 80 dias de replantio. $* *=$ significativo, a $5 \%$ de probabilidade; e $n s=$ não significativo.

Table 1 - Descriptive statistics for the variable volume in the experiment with replanting at different ages in Eucalyptus urophylla $\times$ Eucalyptus grandis clonal stands, in Belo Oriente, Minas Gerais.

Tabela 1 - Estatística descritiva da variável volume no experimento com replantio em diferentes idades em povoamentos clonais de Eucalyptus urophylla $\times$ Eucalyptus grandis, em Belo Oriente, Minas Gerais.

\begin{tabular}{cccc}
\hline Treatment & Average & Standard deviation & CV (\%) \\
\hline 0 & 0.117 & 0.005 & $4.38 \%$ \\
20 & 0.101 & 0.017 & $17.08 \%$ \\
40 & 0.089 & 0.012 & $14.05 \%$ \\
80 & 0.066 & 0.019 & $28.77 \%$ \\
$40 \mathrm{CF}$ & 0.094 & 0.017 & $17.69 \%$ \\
$80 \mathrm{CF}$ & 0.063 & 0.005 & $8.57 \%$ \\
\hline $\mathrm{CF}=$ complementary fertilization; $\mathrm{CV}=$ coefficient of variation. \\
$C F=$ Fertilização complementar; $C V=$ Coeficiente de variação \\
\end{tabular}

\section{DISCUSSIONS}

The initial phase of forest implantation goes from planting until the end of the replanting, which can be done between 45 and 80 days after the beginning of the activities, and any replanting after this, leads to dominated seedlings (Stape et al., 2001). Seedling replanting should be performed if mortality exceeds $10 \%$. Values below $10 \%$ do not represent loss in forest productivity, as long as the failures do not be together, forming a focus (Silva \& Angeli, 2006). Decision-making on replanting takes into account, in addition to technical factors, also economic factors, 


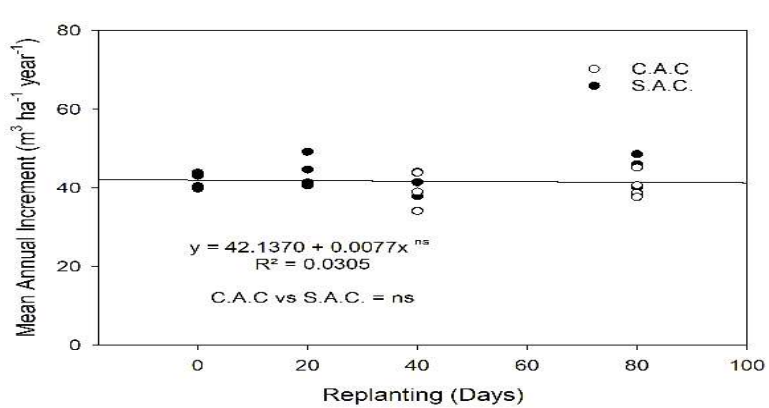

Figure 2 - Average volume increment of Eucalyptus urophylla $\times$ Eucalyptus grandis, at 43 months of age, influenced by the replanting season without complementary planting fertilizer (S.A.C.) and with complementary planting fertilization (C.A.C.) at 40 and 80 days of replanting. ns, not significant, up to $5 \%$ probability, respectively, by the F-test.

Figura 2 - Incremento médio anual em volume das árvores de Eucalyptus urophylla $\times$ Eucalyptus grandis, aos 43 meses de idade, influenciado pela época de replantio sem adubação complementar (S.A.C.) e com adubação complementar (C.A.C.), aos 40 e 80 dias de replantio. $n s=$ não significativo, a $5 \%$ de probabilidade, respectivamente, pelo teste $F$.

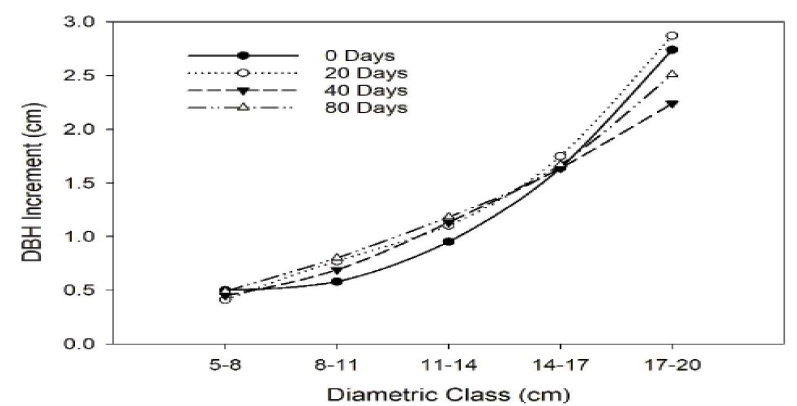

Figure 3 - Increase in DHB of trees from 32 to 43 months of age, for different treatments of replanting season (b), in Eucalyptus urophylla $\times$ Eucalyptus grandis clonal stands.

Figura 3 - Aumento do DAP das árvores dos 32 aos 43 meses de idade, para diferentes tratamentos de época de replantio (b), nos plantios clonais de Eucalyptus urophylla $\times$ Eucalyptus grandis.

Table 2 - Percentage distribution of diameters, considering the dynamics of tree change in diameter classes from 32 to 43 months of age, according to replanting treatments.

Tabela 2 - Distribuição percentual dos diâmetros, considerando a dinâmica da mudança da árvore nas classes de diâmetro dos 32 aos 43 meses de idade, de acordo com os tratamentos de replantio.

\begin{tabular}{ccc}
\hline $\begin{array}{c}\text { Diametric } \\
\text { Class }\end{array}$ & $\begin{array}{c}\text { \% Total Trees } \\
\text { (32 months) }\end{array}$ & $\begin{array}{c}\text { \% Total Trees } \\
\text { (43 months) }\end{array}$ \\
\hline Dead & 4.00 & 4.10 \\
$5-8 \mathrm{~cm}$ & 6.60 & 4.50 \\
$8-11 \mathrm{~cm}$ & 27.50 & 18.00 \\
$11-14 \mathrm{~cm}$ & 52.80 & 40.50 \\
$14-17 \mathrm{~cm}$ & 9.10 & 31.00 \\
$17-20 \mathrm{~cm}$ & 0.00 & 1.90 \\
\hline
\end{tabular}

so that the operation is not economically unviable (Mafia et al., 2005). The coppicing began to gain more attention from researchers and foresters for its economic viability and for satisfactorily meeting the producer's need for wood production (Gonçalves et al., 2014).

The individual volume of the trees from the planting was higher than that presented by the trees from the replanting, regardless of when it was done. The largest production of wood emphasizes the importance of carrying out the activities of planting following quality standards to ensure maximum survival and reduce unnecessary spendings since replanting is a costly activity (Summers et al., 2015). When evaluating the effect of replanting in the growth of seedlings of eucalyptus, differently from the present study, it was observed that when the replanting was made 20 days after planting the growth of the stand was not compromised (Correia et al., 2013). The difference in outcome is explained by the difference in the evaluation season since the authors monitored one year after replanting. By evaluating the effect of plant heterogeneity on the productivity of a eucalyptus forest, it was found that in the absence of genetic and species diversity, heterogeneity of planting has a negative effect on wood volume (Soares et al., 2016).

The complementary fertilization in the replant of the seedlings did not represent a significant increase in their volumetric growth. Plants have nutrient absorption capacity limited to the volume of their root system and their physiological growth (Bordron et al., 2019). The fertilization of eucalyptus plants in higher than adequate doses impairs their development and consequently the quality of the plants (Rocha et al., 2013). Therefore, the availability of additional fertilizer for a replanted seedling is not able to compensate for the loss of productivity due to the difference in days between planting and replanting.

The uniformity of trees in a stand of eucalyptus is a priority in its implementation (Hakamada et al., 2015), however, the growth of larger trees can compensate for the smaller ones, and the final volume will not be compromised (Canh et al., 2013). The main factors that affect the growth of a eucalyptus stand are the productive capacity of the site, the genetic material and the uniformity of the planting. The interaction of these factors can have negative effects

Revista Árvore 2020;44:e4402 
on forest productivity (Resende et al., 2018). This fact was evident in the present study since the AMI did not vary in the tested situations, despite the difference in the individual volume of the trees in replanting.

The greatest variation in the size of the trees in the stand results in higher variability in their growth (Otto et al., 2014). Nevertheless, the efficiency in the use of nutrients in forest species is related to age, where older plants have higher nutritional efficiency compared with those younger (Barros Filho et al., 2017). The lower efficiency in nutrient absorption by the plant hinders its proper development (Nascimento Lima et al., 2005).

The growth rate is higher in trees in higher class center so that the largest trees at an early age will reach higher classes in future ages (Souza et al., 1993). The largest trees can also grow faster than smaller trees in the same stand, efficiently using more resources in timber production (Binkley, 2004). Assessing the effect of different height classes on the growth of a eucalyptus hybrid, it was found by the authors that dominant trees grow larger than suppressed trees due to several factors such as: competition for light, water, and nutrients (Cezana et al., 2012 ).

That is a tendency that replanted seedlings become, over time, trees increasingly dominated inside the stand. This increase in heterogeneity in monoclonal eucalyptus stands can reduce stand-level production by $18-20 \%$ (Stape et al., 2010; Soares et al 2016). In addition to the impacts caused by replanting on stand productivity, it also increases implementation costs.

\section{CONCLUSIONS}

A longer period for the replanting affects negatively the individual volume of the trees and the complementary fertilization of these replanted seedlings does not ensure their best development. Replanting should not be performed, up to $11 \%$ mortality, because it does not positively impact the productivity of the plantation. The final volume of wood is not affected by the replanted seedlings because they become, over time, dominated trees.

\section{REFERENCES}

Alfenas AC, Zauza EAV, Mafia RG, Assis TF. Clonagem e doenças do eucalipto. Viçosa: UFV, 2004. ISBN 9788572692410.
Binkley D, Campoe OC, Alvares C, Carneiro RL, Cegatta I, Stape JL. The interactions of climate, spacing and genetics on clonal Eucalyptus plantations across Brazil and Uruguay. Forest Ecology and Management. 2017; 405: 271-283. doi: https://doi.org/10.1016/j.foreco.2017.09.050

Binkley D. A hypothesis about the interaction of tree dominance and stand production through stand development. Forest Ecology and Management, 2004;190:265-271. 10.1016/j.foreco.2003.10.018

Bordron B, Robin A, Oliveira IR, Guillemot J, Laclau JP, Jourdan C, et al. Fertilization increases the functional specialization of fine roots in deep soil layers for young Eucalyptus grandis trees. Foresty Ecology and Management. 2019; 431 (1): 6 - 16. doi: https://doi.org/10.1016/j.foreco.2018.03.018

Canh T, Binkley D, Luiz J. Neighborhood uniformity increases growth of individual Eucalyptus trees. Forest Ecology and Management. 2013;289:90-97. doi: 10.1016/j.foreco.2012.09.033

Cezana DP, Chichorro JF, Martins LT, Cotta TR, Silva JL. Efeito de diferentes classes de altura e intensidades de desrama artificial sobre o crescimento de um híbrido de eucalipto. Floresta. 2012; 42(1): 137 - 144. Doi: http://dx.doi. org/10.5380/rf.v42i 1.26310

Chichorro JF, Silva ALP, Andrade WSP, Hegedus CEN, Kuboyama FAQ. Custos e índices econômicos de povoamentos de eucalipto do Programa Produtor Florestal no Espírito Santo. Pesquisa Florestal Brasilera. 2017; 37(92): 447 - 456. doi: 10.4336/2017.pfb.37.92.1232

Correia ACG, Santana RC, Oliveira MLR, Titon M, Ataíde GM, Leite FP. Volume de substrato e idade: influência no desempenho de mudas clonais de eucalipto após replantio. Revista Cerne. 2013;19:185-191. doi: 10.1590/S010477602013000200002

Correia ACG, Santana RC, Oliveira MLR, Titon M, Ataíde GM, Leite FP. Volume de substrato e idade: influência no desempenho de mudas clonais de eucalipto após replantio. Cerne. 2013; 19(2): 185 - 191. doi: http://dx.doi.org/10.1590/S010477602013000200002 .

Filho NFB, Schumacher MV, Neves JCL, 
Barros NF, Valadares SV. Tree Growth and Nutrient Dynamics in Pine Plantations in Southern Brazil. Revista Brasileira de Ciência do Solo. 2017; 41(1): 1 - 12. doi: http://dx.doi. org/10.1590/18069657rbcs 20160400

Gonçalves JLM, Alvares CA, Behling M, Alves JM, Pizzi GT, Angeli A. Produtividade de plantações de eucalipto manejadas nos sistemas de alto fuste e talhadia, em função de fatores edafoclimáticos. Scientia Forestalis. 2014;42(103): 411-419. doi: 10.1590/S0104-77602010000200006

Hakamada RE, Stape JL, Lemos CCZ, Emanuel A, Almeida A, Silva LF. Uso do inventário florestal e da uniformidade entre árvores como ferramenta de monitoramento da qualidade silvicultural em plantios clonais de eucalipto. Scientiae Forestalis. 2015; 43(105): $27-39$.

INDÚSTRIA BRASILEIRA DE ÁRVORES (IBÁ). Relatório IBÁ 2017. Disponível em <http://iba.org/ images/shared/Biblioteca/IBA_RelatorioAnual2017. pdf>. Acesso em: 23 de outubro 2017.

Luu TC, Binkley D, Stape JL. Neighborhood uniformity increases growth of individual Eucalyptus trees. Forest Ecology and Management. 2016;89:9097. doi: $10.1016 /$ j.foreco.2012.09.033

Mafia RC, Alfenas AC, Siqueira L, Ferreira EM, Leite HG, Cavallazzi JRP. Critério técnico para determinação da idade ótima de mudas de eucalipto para plantio. Revista Árvore. 2005;29:947-

953. doi: http://dx.doi.org/10.1590/S010067622005000600014.

Nascimento Lima AM, Neves JCL, Silva IR, Leite FP. Cinética de absorção e eficiência nutricional $\mathrm{de} \mathrm{K}+, \mathrm{Ca} 2+$ e $\mathrm{Mg} 2+$ em plantas jovens de quatro clones de eucalipto. Sociedade Brasileira de Ciência do Solo. 2005; 29(6): 903 - 909.

Otto MSG, Hubbard RM, Binkley D, Stape JL. Dominant clonal Eucalyptus grandis x urophylla trees use water more efficiently. Forest Ecology and Management. 2014;328: 117-121. doi: 10.1016/j. foreco.2014.05.032

Queiroz LRS, Barrichelo LEG. The Eucalypt - A century in Brazil. São Paulo: Dutarex S.A., 2007.

Radtke PJ, Westfall JA, Burkhart HE. Conditioning a distance-dependent competition index to indicate the onset of inter-tree competition. Forest Ecology and Management. 2003;175(1-3):17-30. doi: 10.1016/ S0378-1127(02)00118-4

Resende RT, Soares AAV, Forrester DI, Marcatti GE, Santos AR, Takahashi EK, et al. Environmental uniformity, site quality and tree competition interact to determine stand productivity of clonal Eucalyptus. Forest Ecology and Management. 2018; 410(1): 76 - 83. doi: https://doi.org/10.1016/j. foreco.2017.12.038

Rocha JHT, Pietro MR, Borelli K, Backes C, Neves MB. Produção e desenvolvimento de mudas de eucalipto em função de doses de fósforo. Cerne. 2013; 19(4): 535-543. Doi: http://dx.doi.org/10.1590/ S0104-77602013000400002

Schneider PR, Finger CAG, Schneider PSP, Fleig FD, Cunha TA. Influência do espaçamento no autodesbaste de povoamento monoclonal de Eucalyptus saligna Smith. Ciência Florestal. 2015; 25(1): 119 - 126. doi: http://dx.doi. org/10.5902/1980509817468

Silva PHM, Angeli A. Implantação e manejo de florestas comerciais. In: IPEF - Documentos Florestais, no 18. São Paulo: IPEF, 2006. [cited 2019 February 22]. Available from: http://www. rsflorestal.com.br/arquivos/artigos/f/df18.pdf. ISNN: $0103-4715$

Soares AAV, Leite HG, Souza AL, Silva SR, Lourenço HM, Forrester DI. Increasing stand structural heterogeneity reduces productivity in Brazilian Eucalyptus monoclonal stands. Forest Ecology and Management. 2016; 373: 26 - 32. doi: https://doi.org/10.1016/j.foreco.2016.04.035

Soares AAV, Leite HG, Souza AL, Silva SR, Lourenço HM, Forrester DI. Increasing stand structural heterogeneity reduces productivity in Brazilian Eucalyptus monoclonal stands. Forest Ecology and Management. 2016;373:26-32. doi: 10.1016/j.foreco.2016.04.035

Souza AL, Araujo PA, Campos JCC, Paula Neto F. Dinâmica de crescimento em diâmetro de uma floresta primária sem interferência: uma análise pelo tempo de passagem entre classes diamétricas. Revista Árvore. 1993;17:129-145.

Revista Árvore 2020;44:e4402 
Stape JL, Binkley D, Ryan MG, Fonseca S, Loos RA, Takahashi EN, et al. The Brazil Eucalyptus Potential Productivity Project: Influence of water, nutrients and stand uniformity on wood production. Forest Ecology and Management. 2010;259:16841694. doi: $10.1016 /$ j.foreco.2010.01.012

Stape JL, Leonardo J, Gonçalves M, Gonçalves AN. Relationships between nursery practices and field performance for Eucalyptus plantations in Brazil A historical overview and its increasing importance. New Forests. 2001;22(1-2):19-41.
STATSOFT, INC. Statistica (data analysis software system). Version 12. 2014.

Summers DM, Bryan BA, Nolan M, Hobbs TV. The costs of reforestation: A spatial model of the costs of establishing environmental and carbon plantings. Land Use Policy. 2015; 44 (1): 110 - 121. doi: https://doi.org/10.1016/j.landusepol.2014.12.002

Trindade C, Rezende JLP, Jacovine LAG, Sartorio ML. Ferramentas da qualidade: aplicação na atividade florestal. Viçosa: U; 2017. ISBN:9788572695886 